\title{
Solid-state reaction in nanoparticulate alumina/LZSA glass-ceramic composites
}

\section{(Reação em estado sólido em compósitos alumina nanoparticulada/vitrocerâmico LZSA)}

\author{
O.R.K.Montedo ${ }^{1 *}$, F. Raupp-Pereira ${ }^{2}, A . P . N$. de Oliveira ${ }^{2}$ \\ ${ }^{1}$ Universidade do Extremo Sul Catarinense, Programa de Pós-Graduação em Ciência e Engenharia de \\ Materiais, Grupo de Pesquisa em Cerâmica Técnica, Av. Universitária 1105, 88806-000, Criciúma, SC, Brazil \\ ${ }^{2}$ Federal University of Santa Catarina, Graduate Program in Materials Science and Engineering, \\ Laboratory of Glass-Ceramic Materials, PO Box 476, 88040-900, Florianópolis, SC, Brazil
}

\begin{abstract}
In this work, some properties, such as sinterability, modulus of elasticity (E), coefficient of thermal expansion (CTE) and dielectric constant $\left(\varepsilon_{\mathrm{r}}\right)$, of composites constituted by nanoparticulate alumina $\left(27-43 \mathrm{~nm}, 35 \mathrm{~m}^{2} \cdot \mathrm{g}^{-1}\right)$ in different contents $(0$ to $77 \mathrm{vol} \%)$ and a LZSA glass-ceramic composition $\left(17.7 \mathrm{Li}_{2} \mathrm{O}-5.2 \mathrm{ZrO}_{2}-68.1 \mathrm{SiO}_{2}-9.0 \mathrm{Al}_{2} \mathrm{O}_{3}\right.$, molar basis) were evaluated. Dry powders of the raw materials (alumina and LZSA parent glass, frit) were uniaxially pressed (40 MPa) and the obtained compacts were sintered at 600 $950{ }^{\circ} \mathrm{C}(1 \mathrm{~h}$ holding time). X-ray diffraction (XRD) study was performed in order to investigate the solid-state reactions occurred in LZSA-based compositions during sintering. XRD results were correlated to the CTE, E and $\varepsilon_{\mathrm{r}}$ of sintered samples. The CTE of the obtained composites decreased as alumina content increased mainly due to the $\beta$-spodumene ${ }_{\mathrm{ss}}$ (solid solution $\mathrm{Li}_{2} \mathrm{O} \cdot \mathrm{Al}_{2} \mathrm{O}_{3} \cdot 4-10 \mathrm{SiO}_{2}$ ) formation. The results concerning the $\mathrm{E}(22.3 \pm 1.5 \mathrm{GPa})$ and $\varepsilon_{\mathrm{r}}(3.1 \pm 1.3)$ for the composite with 5.6 vol\% addition sintered at $850{ }^{\circ} \mathrm{C}$ for $1 \mathrm{~h}$ indicated, in a preliminary way, the possibility of development of materials with suitable properties for applications concerning to the low temperature co-fired ceramic (LTCC) technology.
\end{abstract}

Keywords: glass-ceramics, alumina nanoparticles, composites, sintering, solid-state reaction.

Resumo

Neste trabalho foram avaliadas algumas propriedades, como sinterabilidade, módulo de elasticidade (E), coeficiente de expansão térmica $(C E T)$ e constante dielétrica $\left(\varepsilon_{r}\right)$, em compósitos de nanopartículas de alumina $\left(27-43 \mathrm{~nm}, 35 \mathrm{~m}^{2} . \mathrm{g}^{-1}\right)$ em vários teores $(0$ a 77 vol\%) e uma composição vitrocerâmica $\mathrm{LZSA}\left(17,7 \mathrm{Li}_{2} \mathrm{O}-5,2 \mathrm{ZrO}_{2}-68,1 \mathrm{SiO}_{2}-9,0 \mathrm{Al}_{2} \mathrm{O}_{3}\right.$, em base molar). Pós secos das matériasprimas empregadas (alumina e vidro precursor de LZSA) foram prensados uniaxialmente (40 MPa) e os compactos obtidos foram sinterizados a $600-950^{\circ} \mathrm{C}(1 \mathrm{~h}$ de patamar). Estudos de difração de raios $X(D R X)$ foram realizados para se investigar as reações em estado sólido que ocorreram nas composições à base dos vitroceramicos LZSA durante a sinterização. Os resultados de DRX foram relacionados com o CET, E e $\varepsilon_{r}$ das amostras sinterizadas. O CET dos compósitos obtidos diminuiu com o aumento do teor de alumina principalmente devido à formação de espodumênio- $\beta$ ss ( solução sólida $\mathrm{Li}_{2} \mathrm{O}_{\mathrm{Al}} \mathrm{Al}_{2} \mathrm{O}_{3} \cdot 4-10 \mathrm{SiO}_{2}$ ). Os resultados relativos ao $\mathrm{E}$ $(22,3 \pm 1,5 \mathrm{GPa})$ e $\varepsilon_{r}(3,1 \pm 1,3)$ para o compósito com 5,6 vol\% de adição, sinterizado a $850^{\circ} \mathrm{C}$ por $1 \mathrm{~h}$, indicaram primariamente a possibilidade de desenvolvimento de materiais com propriedades adequadas para aplicações relacionadas à tecnologia de LTCC (low temperature co-fired ceramics).

Palavras-chave: vitrocerâmicos, nanopartículas de alumina, compósitos, sinterização, reação em estado sólido.

\section{INTRODUCTION}

In 1940's and 1950's, in the United States, two independent research lines revealed the prospect of a new family of materials presenting high potential application, which is known as glass-ceramics [1]. The first one was conducted by Donald Stookey at Corning Glass Works when studying glass nucleation. Stookey accidentally discovered that some of the photon-nucleated glasses he had been investigating turned into highly crystalline

*oscar.rkm@gmail.com materials with a very fine microstructure (crystals in the order of microns) by means of an annealing process. The second line of research began with the discovery by F.A. Hümmel in 1951 that crystalline aggregates of $\beta$-eucryptite $\left(\mathrm{Li}_{2} \mathrm{O} \cdot \mathrm{Al}_{2} \mathrm{O}_{3} \cdot 2 \mathrm{SiO}_{2}\right)$ resulted in materials showing the negative coefficient of thermal expansion (CTE). For decades, synthetic glass-ceramics have been studied to understand their thermal behavior and also the relationship between composition, processing and microstructure. In the last decades, different applications for glass-ceramics have been studied based on their mechanical [2-5], thermal [68], electrical [9-12], biological [3, 13-16], and optical [17- 
19] properties, among others. Glass-ceramics are produced from a controlled crystallization of a glass that generates a microstructure formed by one or more crystalline phases, eventually some porosity, and a residual glassy phase, since crystallinity ranges from 0.5 to $99.5 \%$, although it achieves typical values between 30 and 70\% [20]. The residual glassy phase can prevent better properties to be achieved. Residual stresses can be generated in glass-ceramics depending on the crystalline phases and their relative amounts. According to [21], residual stress can be determined by measuring the peak displacement of X-ray reflections. In such method, a stressfree powdered $\beta$-eucrypite and $\beta$-spodumene solid-solution based glass-ceramic with high crystallized volume fractions were used as reference materials.

Some works have been conducted toward to add nanoparticles for reacting with the glassy phase in order to increase the crystallinity. Arcaro et al. [10] added $\alpha$-alumina (1-40 vol\%) particles $(350 \mathrm{~nm})$ to a $19.58 \mathrm{Li}_{2} \mathrm{O}-11.10 \mathrm{ZrO}_{2}-$ $69.32 \mathrm{SiO}_{2}\left(\mathrm{~mol} \%, \mathrm{~d}_{50}=\sim 5 \mu \mathrm{m}\right)$ glass-ceramic composition to react with lithia and silica present in the glassy phase and form $\beta$-spodumene $\left(\mathrm{Li}_{2} \mathrm{O}_{2} \mathrm{Al}_{2} \mathrm{O}_{3} \cdot 4 \mathrm{SiO}_{2}\right)$. Cesconeto et al. [22] studied the addition of $\mathrm{TiO}_{2}(0-50$ vo $1 \%)$ nanoparticles $(25 \mathrm{~nm})$ to a $11.7 \mathrm{Li}_{2} \mathrm{O}-12.6 \mathrm{ZrO}_{2}-68.6 \mathrm{SiO}_{2}-7.1 \mathrm{Al}_{2} \mathrm{O}_{3}$, LZSA $(4 \mu \mathrm{m})$ glassceramic matrix, to prepare compositions for low temperature co-fired ceramics (LTCCs) applications. The relative densities of sintered composites $\left(700-1000{ }^{\circ} \mathrm{C} / 30 \mathrm{~min}\right.$ ) increased (up to 98\%) and showed $\beta$-spodumene, $\mathrm{TiO}_{2}$ and $\mathrm{Li}_{2} \mathrm{TiSiO}_{5}$ as main crystalline phases. Arcaro et al. [23] added nano-sized $\mathrm{Al}_{2} \mathrm{O}_{3}$ particles (1-5 vol\%) and submicrometric $\mathrm{Al}_{2} \mathrm{O}_{3}$ particles (5 vol\%) to a $19.58 \mathrm{Li}_{2} \mathrm{O}-11.10 \mathrm{ZrO}_{2}-69.32 \mathrm{SiO}_{2}(\mathrm{~mol} \%)$ glassceramic matrix. The formation of $\beta$-spodumene in the obtained composites lead to reduce the coefficient of thermal expansion (CTE), whose values ranged from $9.5 \times 10^{-6}$ to $4.4 \times 10^{-6}{ }^{\circ} \mathrm{C}^{-1}$. Composites with 5\% nano-sized alumina showed a CTE lower than that of the equivalent formulation with submicrometric alumina. Glass-ceramics produced from the $\mathrm{LZSA}\left(\mathrm{Li}_{2} \mathrm{O}-\mathrm{ZrO}_{2}-\right.$ $\mathrm{SiO}_{2}-\mathrm{Al}_{2} \mathrm{O}_{3}$ ) glass system have been studied [24-28] since they show low CET and are chemically resistant materials. However, the properties of such glass-ceramics can also be improved by increasing the crystallinity. Thus, this work aimed to evaluate the effect of the alumina nanoparticles addition to a $17.7 \mathrm{Li}_{2} \mathrm{O}-$ $5.2 \mathrm{ZrO}_{2}-68.1 \mathrm{SiO}_{2}-9.0 \mathrm{Al}_{2} \mathrm{O}_{3}$ glass-ceramic matrix by increasing the $\beta$-spodumene content by means of solid-state reaction in samples sintered at different thermal cycles.

\section{EXPERIMENTAL}

Compositions containing 0 to $77 \mathrm{vol} \%$ of $\alpha$-alumina nanoparticles $\left(27-43 \mathrm{~nm}\right.$ APS, $35 \mathrm{~m}^{2} \cdot \mathrm{g}^{-1} \mathrm{SSA}, 3.88 \mathrm{~g} . \mathrm{cm}^{-3}$ density) and a $17.7 \mathrm{Li}_{2} \mathrm{O}-5.2 \mathrm{ZrO}_{2}-68.1 \mathrm{SiO}_{2}-9.0 \mathrm{Al}_{2} \mathrm{O}_{3}$ parent glass (molar basis), frit (2.34 $\mu \mathrm{m}$ mean particle size, 2.62 g. $\mathrm{cm}^{-3}$ density) were prepared (Table I). Further details on the preparation and processing of the LZSA glass frit can be obtained in [25]. The glass was obtained from the melting $\left(1550 \pm 3^{\circ} \mathrm{C}\right.$ for $2 \mathrm{~h}$ ) in an electrical furnace (Nabertherm LHT 02/17 LBR, Germany) of the appropriate amounts of lithium carbonate, zircon, quartz and alumina of high purity (over 99.5\%) in a platinum crucible. Then, melts were poured out into deionized water to obtain frits.

Powders of each composition were dry-mixed in a porcelain ball mill (60 wt $\%$ of solids, $30 \%$ apparent volume of balls, balls of $5 \mathrm{~mm}$ diameter) for $10 \mathrm{~min}$. Apparent densities of the compacted (40 MPa, $50 \mathrm{~mm}$ length, $10 \mathrm{~mm}$ width and $7 \mathrm{~mm}$ height) and sintered specimens were determined geometrically. Glass transition $\left(\mathrm{T}_{\mathrm{g}}, 580^{\circ} \mathrm{C}\right)$ and crystallization temperature $\left(\mathrm{T}_{\mathrm{c}}, 794{ }^{\circ} \mathrm{C}\right)$ were determined in a differential scanning calorimeter (DSC 404C, Netzsch, Germany; alumina crucibles, dry air, $10{ }^{\circ} \mathrm{C} \cdot \mathrm{min}^{-1}$ heating rate). The linear shrinkage (LS) behavior and the coefficient of thermal expansion (CTE) of the compositions were measured with a horizontal dilatometer (DIL 402C, Netzsch, Germany; heating rate of $\left.10^{\circ} \mathrm{C} \cdot \mathrm{min}^{-1}\right)$. Specimens were heat-treated (sintered) at different temperatures $\left(600-850{ }^{\circ} \mathrm{C}\right)$ and $1 \mathrm{~h}$ holding time in an electrically heated furnace (LM 421.27, Linn High Therm, Germany; heating rate of $\left.10{ }^{\circ} \mathrm{C} \cdot \mathrm{min}^{-1}\right)$. Theoretical densities of the compositions obtained at different temperatures were estimated considering the theoretical densities of alumina and glass-ceramic and respective contents in the compositions. Relative densities at several temperatures were calculated taking into account the ratio between apparent and theoretical densities of the heat-treated specimens. X-ray diffractometry studies were performed in an X-ray diffractometer (XRD, Siemens D500, Siemens AG, Germany) from powdered samples in order to investigate the reactions occurring in LZSA-based compositions. Monochromated $\mathrm{CuK} \alpha 1$ radiation was applied at a voltage of $30 \mathrm{kV}$ and a current of $30 \mathrm{~mA}$. Elastic modulus was determined by a transitory vibration analyzer (ATCP Eng. Física, Sonelastic, Brazil). Dielectric constant measurements were carried out according to DIN 53 482/VDE 0303 in an HP Dielectric Test Fixture (16451B, Hewlett Packard, Germany) at room temperature applying a frequency of $1 \mathrm{MHz}$. Disc samples with $20 \mathrm{~mm}$ diameter and $1.2 \mathrm{~mm}$ thickness were heat-treated at $850{ }^{\circ} \mathrm{C}$ for $1 \mathrm{~h}$. After heat treatments, each sample was transversally cut. Microstructures were analyzed by scanning electron microscopy (SEM, Philips XL 30, Netherlands).

\section{RESULTS AND DISCUSSION}

Firstly, the effect of alumina nanoparticles in the formation of crystalline phases of LZSA glass-ceramic (P) is shown in Fig. 1a. As identified in previous works [24-

Table I - Alumina content of the studied compositions.

[Tabela I - Teor de alumina das composições estudadas.]

\begin{tabular}{cccccccc}
\hline Composition & P & L08A & L1A & L3A & L5A & L7A & L8A \\
\hline Alumina content (vol\%) & 0 & 5.6 & 11.9 & 25.3 & 40.3 & 57.4 & 77.3 \\
\hline
\end{tabular}


28], a solid solution of $\beta$-spodumene $\left(\mathrm{Li}_{0-6} \mathrm{Al}_{0-6} \mathrm{Si}_{2-4} \mathrm{O}_{6}\right)$ and zirconium silicate $\left(\mathrm{ZrSiO}_{4}\right)$ were the main crystalline phases formed in this glass-ceramic system, although a residual glassy phase was also observed. However, the solid solution of $\beta$-spodumene ( $\beta$-spodumene ss $_{\text {ss }}$ ) represents a family of lithium aluminosilicate crystalline phases, which main diffraction peaks are very similar. Actually, an overlap occurred in some of them. Here, nevertheless, such crystalline phases are evaluated separately in order to show the effect of the alumina nanoparticles addition. Fig. 1a shows that $\beta$-spodumene $\left(\mathrm{Li}_{0-6} \mathrm{Al}_{0-6} \mathrm{Si}_{2-4} \mathrm{O}_{6}, \mathrm{ICCD}\right.$ - International Centre for Diffraction Data, file no. 21-503), $\mathrm{LiAlSi}_{3} \mathrm{O}_{8}$ (ICCD 1527) and zirconium silicate $\left(\mathrm{ZrSiO}_{4}, \mathrm{ICCD} 6-266\right)$ increased their relative amounts, considering the relative heights of the respective peaks, from 700 to $850{ }^{\circ} \mathrm{C}$. Lithium metasilicate $\left(\mathrm{Li}_{2} \mathrm{SiO}_{3}, \mathrm{ICCD} 29-829\right)$ is residual lithium-based crystalline phase [1,23-25], supposedly because of the lack of aluminum available in the liquid phase to form a more complex
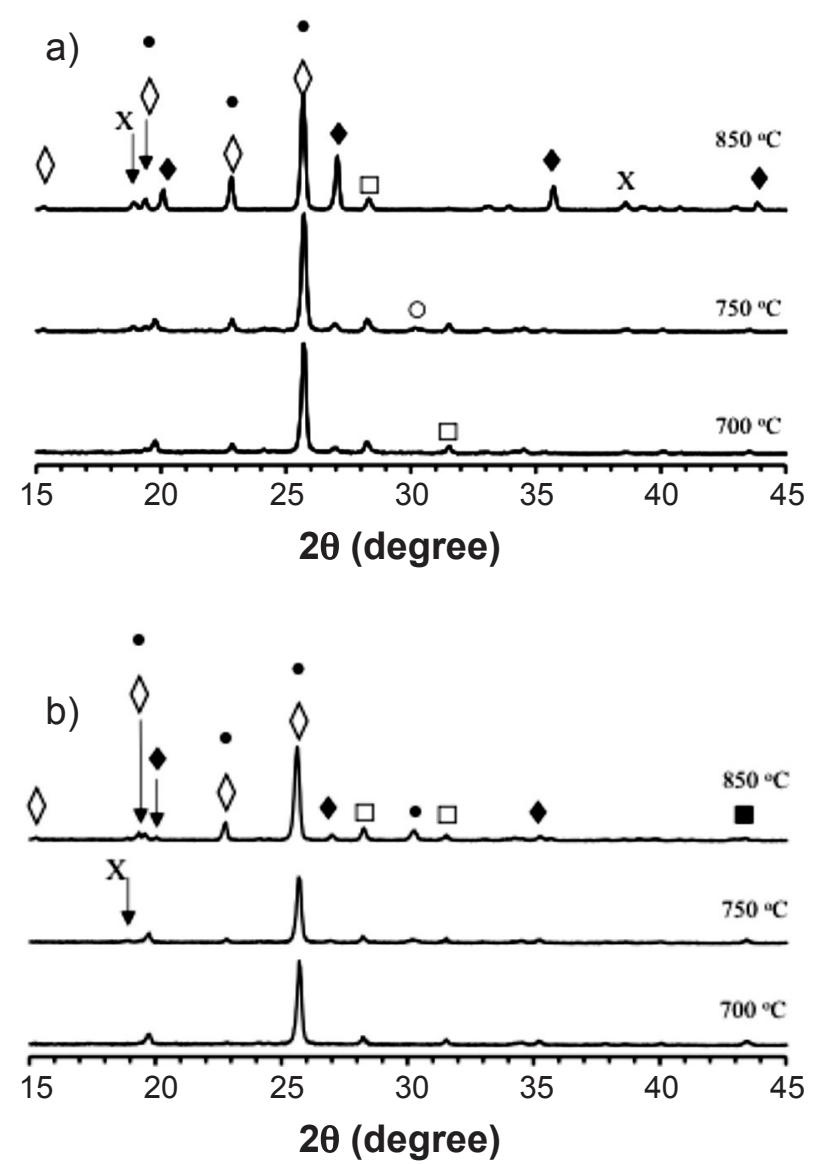

Figure 1: X-ray diffraction patterns of LZSA glass-ceramic (a) and composition L1A (b) sintered at different temperatures (700-850 ${ }^{\circ} \mathrm{C}, 1 \mathrm{~h}$ holding time): $\bullet \beta$-spodumene $\left(\mathrm{LiAlSi}_{2} \mathrm{O}_{6}\right)$, $\diamond \mathrm{LiAlSi}_{3} \mathrm{O}_{8}, \mathrm{X}$ lithium metasilicate $\left(\mathrm{Li}_{2} \mathrm{SiO}_{3}\right)$, zirconium silicate $\left(\mathrm{ZrSiO}_{4}\right), \square$ zirconium oxide $\left(\mathrm{ZrO}_{2}\right), \boldsymbol{\alpha} \alpha$-alumina $\left(\mathrm{Al}_{2} \mathrm{O}_{3}\right), \mathrm{O}$ tridimite $\left(\mathrm{SiO}_{2}\right)$.

[Figura 1: Difratogramas de raios $X$ do vitrocerâmico LZSA (a) e da composição L1A (b) sinterizados em diferentes temperaturas (700-850 ${ }^{\circ} \mathrm{C}, 1 \mathrm{~h}$ de patamar): • espodumênio- $\beta$, $\diamond \mathrm{LiAlSi}_{3} \mathrm{O}_{8}, \mathrm{X}$ metassilicato de lítio, silicato de zircônio, $\square$ óxido de zircônio, Dalumina- $\alpha$, $\bigcirc$ tridimita.] crystalline phase, such as a lithium aluminosilicate. Because of this, an addition of alumina could react with $\mathrm{Li}_{2} \mathrm{SiO}_{3}$. Fig. $1 \mathrm{~b}$ shows the XRD patterns of composition L1A (11.9 vol\% of alumina). At $850{ }^{\circ} \mathrm{C}$, one may see that apparently $\mathrm{Li}_{2} \mathrm{SiO}_{3}$ was consumed to form $\mathrm{LiAlSi}_{2} \mathrm{O}_{6}$ or $\mathrm{LiAlSi}_{3} \mathrm{O}_{8}$. It seems that such lithium aluminosilicates increased their relative amounts in relation to the other crystalline phases in comparison to composition P (LZSA glass-ceramic), except apparently for zirconium oxide. Moreover, a residual amount of $\alpha$-alumina (ICCD 43-1484, 42-1468 and 10-0173) can be observed in Fig. $1 \mathrm{~b}$ with $\mathrm{I} / \mathrm{I}_{1}=100$ at $\mathrm{d}=2.085 \AA \mathrm{O}\left(2 \theta=\sim 43.3^{\circ}\right)$. Apparently, the relative amount of $\alpha$-alumina decreased from 700 to $850{ }^{\circ} \mathrm{C}$. Such structural modifications interfered on the CTE of the studied composites.

The addition of alumina nanoparticles should change the thermal behavior of the glass-ceramic. Thus, the effect of alumina nanoparticle addition in the LS behavior of the composition $\mathrm{P}$ was evaluated. Fig. 2 shows the LS behavior of the studied compositions. As it can be seen, the sintering of LZSA glass-ceramic (P) occurred between 600 and 800 ${ }^{\circ} \mathrm{C}$, as previously reported [25-28]. However, the addition of alumina nanoparticles increased the sintering start temperature and the sintering range. Moreover, as expected, the maximum LS decreased with the increase of alumina nanoparticle addition. Such thermal behavior interfered in porosity. In fact, Fig. 3 shows that the addition of alumina nanoparticles increased the porosity, because of the reduction of LS in relation to the alumina addition. Considering
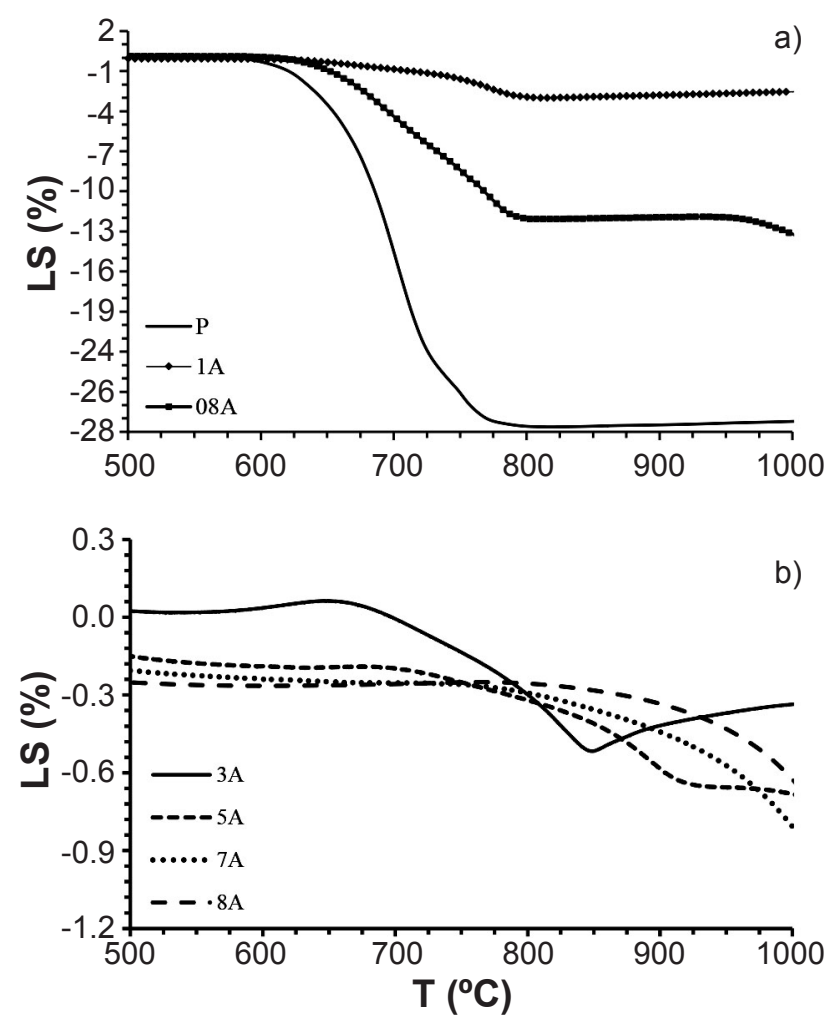

Figure 2: Linear shrinkage (LS) as a function of temperature for studied compositions.

[Figura 2: Retração linear (LS) em função da temperatura para as composições estudadas.] 


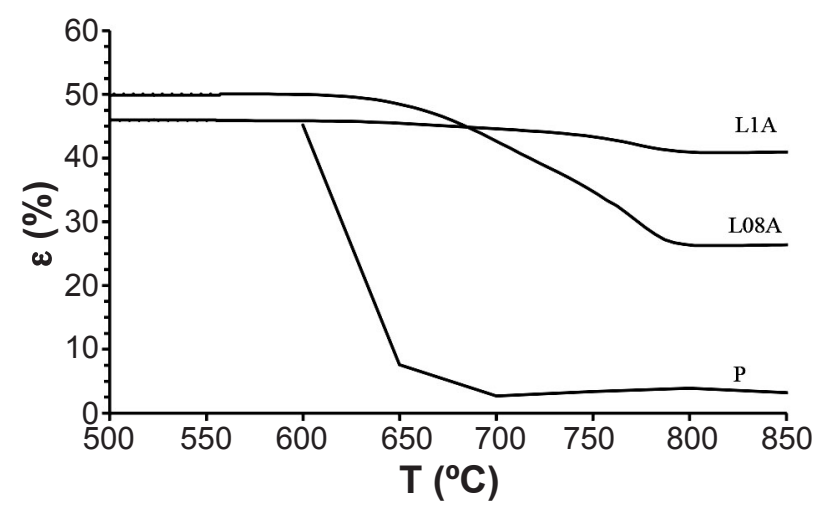

Figure 3: Porosity $(\varepsilon)$ as a function of temperature for compositions P, L08A and L1A.

[Figura 3: Porosidade (E) em função da temperatura para as composições P, LOSA e L1A.]

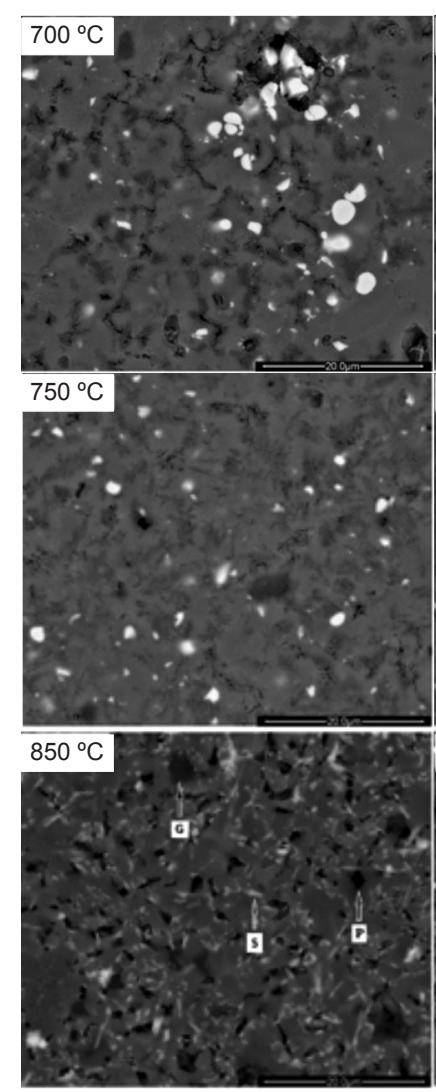

(a)

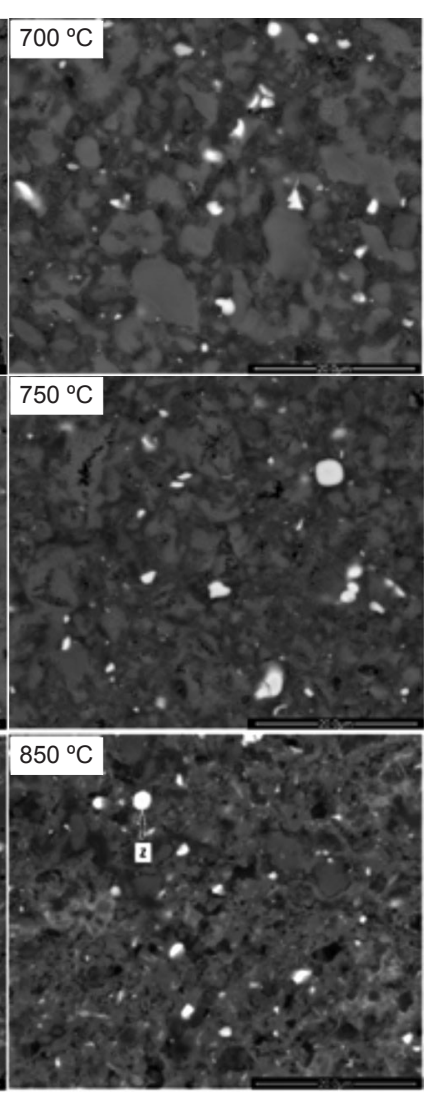

(b)
Figure 4: SEM micrographs of compositions P (a) and L1A (b) sintered at different temperatures $\left(700-850{ }^{\circ} \mathrm{C}\right)$ for $1 \mathrm{~h}: \mathrm{G}$ - residual glassy phase; $\mathrm{P}$ - pore; $\mathrm{S}$ - $\beta$-spodumene; $\mathrm{Z}$ - zirconium silicate.

[Figura 4: Micrografias obtidas por microscopia eletrônica de varredura das composições $P(a)$ e L1A (b) sinterizadas em diferentes temperaturas (700-850 ${ }^{\circ} \mathrm{C}$ ) por $1 \mathrm{~h}: \mathrm{G}$ - fase vítrea residual; $P$ - poro; $S$ - espodumênio- $\beta ; Z$ - silicato de zircônio.]

such behavior, the temperature of $850{ }^{\circ} \mathrm{C}(1 \mathrm{~h}$ holding time) was chosen to produce sintered samples for further characterization. Porosities between 7 and $15 \%$ are found in ceramic materials for LTCC application [10]. Although composition L1A showed much higher porosity in relation to composition $\mathrm{P}$ at $850^{\circ} \mathrm{C} / 1 \mathrm{~h}$, micrographs (Fig. 4) do not
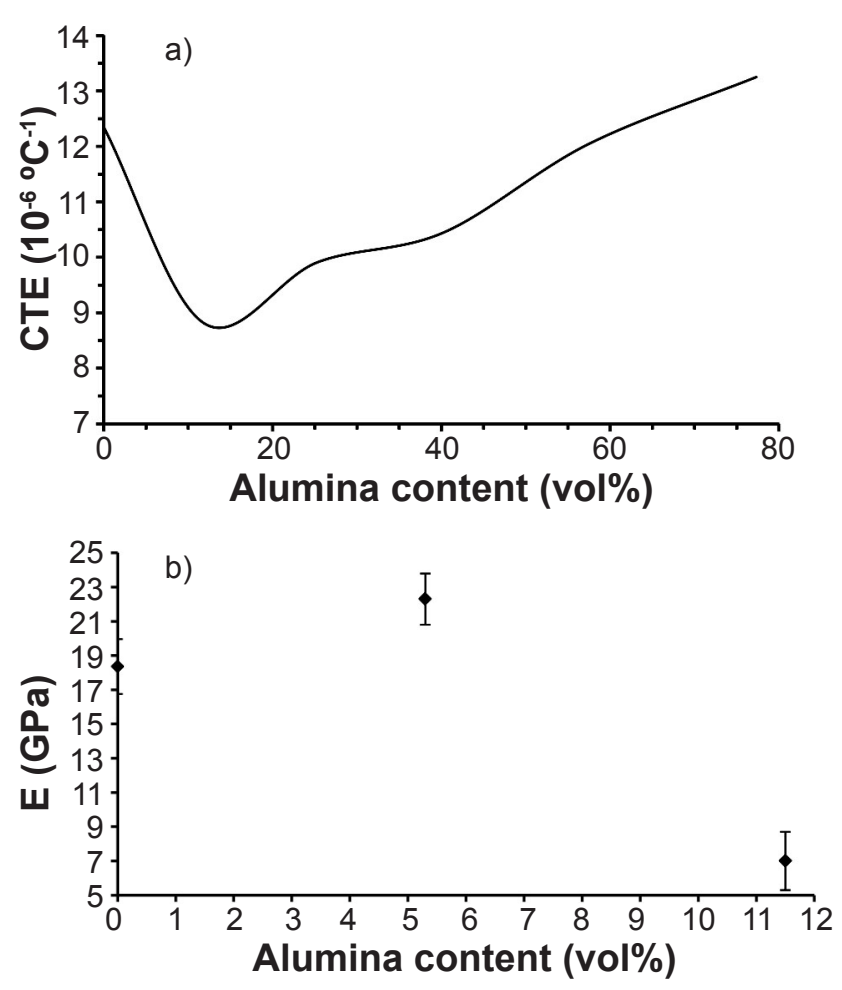

Figure 5: CTE (30-700 ${ }^{\circ} \mathrm{C}$ ) (a) and modulus of elasticity, E (b), as a function of alumina nanoparticle content for samples sintered at $850{ }^{\circ} \mathrm{C}$ for $1 \mathrm{~h}$.

[Figura 5: CET (30-700 $\left.{ }^{\circ} \mathrm{C}\right)$ (a) e módulo de elasticidade, E (b), em função do teor de alumina nanoparticulada de amostras sinterizadas a $850^{\circ} \mathrm{C}$ por $\left.1 \mathrm{~h}.\right]$

show significant differences between microstructures of compositions $\mathrm{P}$ and L1A, because the used magnification may not show the higher and the smaller pores in L1A. However, significant changes in properties were observed because of the addition of alumina nanoparticles to the LZSA glass-ceramic.

The addition of alumina nanoparticles promotes the reaction of $\mathrm{Li}_{2} \mathrm{O}$ and $\mathrm{SiO}_{2}$ present in the residual glassy phase and promotes the $\beta$-spodumene solid solution formation, which shows low CTE [10]. Because of this, at low alumina nanoparticle additions, the CTE was low in relation to LZSA glass-ceramic, but it increased at higher alumina nanoparticle contents, because of the higher CTE of the glassy phase and alumina $\left(8.4 \times 10^{-6}{ }^{\circ} \mathrm{C}^{-1}, 0\right.$ to $1300{ }^{\circ} \mathrm{C}$ [29]). Fig. 5a shows that the CTE decreased from $12.3 \times 10^{-6}{ }^{\circ} \mathrm{C}^{-1}$ (composition P) up to $8.8 \times 10^{-6}{ }^{\circ} \mathrm{C}^{-1}$ at $\sim 13$ vol\% alumina nanoparticles and increased again with higher additions. Arcaro et al. [10] found values between 9.54 and $3.36 \times 10^{-6}{ }^{\circ} \mathrm{C}^{-1}$ for LTCC applications. Thus, for the investigated glass-ceramic composition, the maximum addition of alumina nanoparticles is $\sim 13 \mathrm{vol} \%$ if the objective is the obtainment of a low CTE glass-ceramic. Nevertheless, such addition value is different of course for another LZSA composition, since it depends on the residual $\mathrm{Li}_{2} \mathrm{SiO}_{3}$ amount or lithium remaining into residual glassy phase. Fig. $5 \mathrm{~b}$ shows the effect of the alumina nanoparticle addition on the modulus of elasticity (E). E increased from 
Table II - Dielectric constant $\left(\varepsilon_{\mathrm{r}}\right)$ and dielectric loss $(\tan \delta)$ of the studied compositions sintered at $850^{\circ} \mathrm{C}$ for $1 \mathrm{~h}$.

[Tabela II - Constante dielétrica $\left(\varepsilon_{r}\right)$ e perda dielétrica (tanठ) das composições sinterizadas a $850{ }^{\circ} \mathrm{C}$ por $\left.1 \mathrm{~h}.\right]$

\begin{tabular}{ccc}
\hline Composition & $\varepsilon_{\mathrm{r}}$ & $\tan \delta$ \\
\hline P & $7.81 \pm 0.66$ & $0.03 \pm 0.01$ \\
L08A & $3.07 \pm 1.29$ & $0.07 \pm 0.04$ \\
L1A & $1.40 \pm 0.09$ & $0.04 \pm 0.01$ \\
L5A & $1.31 \pm 0.05$ & $0.13 \pm 0.01$ \\
\hline
\end{tabular}

$18.3 \mathrm{GPa}(0 \mathrm{vol} \%$ addition) up to $22.3 \pm 1.5 \mathrm{GPa}$ (5.6 vol\% addition) and then decreased probably because of the nonreacted alumina and the increase in porosity. Thus, low alumina additions (6-10 vol\%) improve CTE and E of alumina nanoparticles-LZSA glass-ceramic compositions because of the increase of lithium aluminosilicates formation, but at higher alumina contents, E diminishes because of the increase in porosity.

The addition of alumina nanoparticles to the LZSA glass-ceramic also influenced the dielectric constant. Table II shows that the increase of alumina nanoparticles content decreased the dielectric constant $\left(\varepsilon_{\mathrm{r}}\right)$ probably because of the increase in porosity. Gomes et al. [30] found $\varepsilon_{\mathrm{r}}$ values of $8.39-8.61$ for a $17.65 \mathrm{Li}_{2} \mathrm{O}-5.20 \mathrm{ZrO}_{2}-68.15 \mathrm{SiO}_{2}-$ $9.00 \mathrm{Al}_{2} \mathrm{O}_{3}$ composition, molar basis. Arcaro [31] found values of 6.11-7.12 for 5 vol\% alumina addition to a 19.58 $\mathrm{Li}_{2} \mathrm{O}-11.10 \mathrm{ZrO}_{2}-69.32 \mathrm{SiO}_{2}$ composition. Dernovsek et al. [32] found dielectric constant values between 25 and 70 for glass-ceramic composites in the system $\mathrm{BaO}-\mathrm{Nd}_{2} \mathrm{O}_{3}$ $\mathrm{TiO}_{2}$ and modified rare earth glasses based on boron oxide. Electrical conductivity as low as $10^{-10} \mathrm{~S} . \mathrm{m}^{-1}$ and $\varepsilon_{\mathrm{r}}$ values ranging from 41 to 104 (at $300{ }^{\circ} \mathrm{C}$ ) in glass-ceramics sintered below $950{ }^{\circ} \mathrm{C}$ has been reported [33] as some requirements for commercial LTCCs.

\section{CONCLUSIONS}

The effect of nanoparticulate alumina additions on the formation of aluminosilicates formed by solidstate reaction in an LZSA glass-ceramic composition (17.7 $\mathrm{Li}_{2} \mathrm{O}-5.2 \mathrm{ZrO}_{2}-68.1 \mathrm{SiO}_{2}-9.0 \mathrm{Al}_{2} \mathrm{O}_{3}$, molar basis) was investigated. $\mathrm{X}$-ray diffraction study showed that the addition of alumina nanoparticles reduced the lithium metasilicate amount and increased the aluminosilicatebased crystalline phases. Such structural changes interfered in the coefficient of thermal expansion (CTE), modulus of elasticity (E) and dielectric constant of the sintered samples at $850{ }^{\circ} \mathrm{C}$ for $1 \mathrm{~h}$. Lower values of CTE $\left(\sim 9 \times 10^{-6}{ }^{\circ} \mathrm{C}^{-1}\right)$ and higher values of E $(\sim 20 \mathrm{GPa})$ were obtained between 5.6-10 vol\% alumina addition.

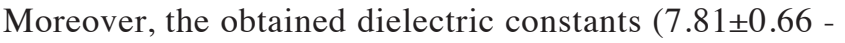
$1.31 \pm 0.05)$ indicated, in a preliminary way, the possibility of development of materials with suitable properties for applications concerning to the low temperature co-fired ceramics (LTCC) technology.

\section{ACKNOWLEDGEMENTS}

Authors are very grateful to Conselho Nacional de Desenvolvimento Científico e Tecnológico (CNPq/ Brazil, Process n. 308669/2016-9) and Coordenação de Aperfeiçoamento de Pessoal de Nível Superior (CAPES/ Brazil) for supporting this study.

\section{REFERENCES}

[1] W. Pannhorst, in: "Low thermal expansion glass ceramics", Ed. H. Bach, Springer, Germany (1995) 1.

[2] A.R. Molla, B.V.M. Kumar, B. Basu, J. Eur. Ceram. Soc. 29 (2009) 2481.

[3] A. Theocharopoulos, L. Zoua, R. Hill, M. Cattell, Wear 269 (2010) 930.

[4] D. Herman, T. Okupski, W. Walkowiak, J. Eur. Ceram. Soc. 31 (2011) 485.

[5] R.L.P. Santos, M. Buciumeanu, F.S. Silva, J.C.M. Souza, R.M. Nascimento, F.V. Motta, O. Carvalho, B. Henriques, Trib. Int. 102 (2016) 361.

[6] M.J. Pascual, V.V. Kharton, E. Tsipis, A.A. Yaremchenko, C. Lara, A. Durán, J.R. Frade, J. Eur. Ceram. Soc. 26 (2006) 3315 .

[7] M. Rathore, A. Dalvi, A. Kumar, W. Ślubowska, J.L. Nowinski, Solid State Ionics 282 (2015) 76.

[8] M. Marangoni, B. Nait-Ali, D.S. Smith, M. Binhussain, P. Colombo, E. Bernardo, J. Eur. Ceram. Soc. 37 (2017) 1117.

[9] M. Tatsumisago, A. Hayashi, Solid State Ionics 225 (2012) 342 .

[10] S. Arcaro, F.R. Cesconeto, F. Raupp-Pereira, A.P. Novaes de Oliveira, Ceram. Int. 40 (2014) 5269.

[11] O.R.K. Montedo, I.T. Alves, C.A. Faller, F.M. Bertan, D.H. Piva, R.H. Piva, Mat. Res. Bull. 72 (2015) 90.

[12] S. Hasegawa, K. Shinozaki, T. Honma, V. Dimitrov, H.G. Kim, T. Komatsu, J. Non-Cryst. Sol. 452 (2016) 74.

[13] L. Lin, L. Zhang, J. Wang, K. Xie, X. Yang, X. Chen, G. Yang, C. Gao, Z. Gou, Mater. Lett. 126 (2014) 154.

[14] M. Diba, O.-M. Goudouri, F. Tapia, A.R. Boccaccini, Curr. Opin. Solid State Mater. Sci. 18 (2014) 147.

[15] M. Dziadek, B. Zagrajczuk, E. Menaszek, A. Wegrzynowicz, J. Pawlik, K. Cholewa-Kowalska, Ceram. Int. 42 (2016) 5842.

[16] H.M. Fathi, A. Johnson, Dent. Mater. 32 (2016) 311.

[17] S. Singh, K. Singh, J. Non-Cryst. Sol. 386 (2014) 100. [18] Z. Zhang, Y. Zhang, Z. Feng, W. Cheng, H. Xia, X. Zhang, J. Rare Earth. 34 (2016) 464.

[19] M. Kemere, J. Sperga, U. Rogulis, G. Krieke, J. Grube, J. Lumin. 181 (2017) 25.

[20] E.D. Zanotto, Am. Ceram. Soc. Bull. 89 (2010) 19.

[21] L. Zevin, E. Levi, Z. Bessmertnaya, Inorg. Mater. 13 (1977) 1511.

[22] F.R. Cesconeto, S. Arcaro, F. Raupp-Pereira, J.B. Rodrigues Neto, D. Hotza, A.P Novaes de Oliveira, Ceram. Int. 40 (2014) 9535.

[23] S. Arcaro, M.I. Nieto, R. Moreno, A.P. Novaes de 
Oliveira, Ceram. Int. 42 (2016) 8620.

[24] O.R.K. Montedo, F.M. Bertan, R. Piccoli, A.P. Novaes de Oliveira, Am. Ceram. Soc. Bull. 87 (2008) 34.

[25] O.R.K. Montedo, D. Hotza, A.P. Novaes de Oliveira, R. Meszaros, N. Travitzky, P. Greil, Adv. Mat. Sci. Eng. 2012 (2012) 1.

[26] O.R.K. Montedo, F.J. Floriano, J. de Oliveira Filho, A.M. Bernardin, Mater. Res. 12 (2009) 197.

[27] O.R.K. Montedo, F.J. Floriano, J. de Oliveira Filho, C.M. Gomes, D. Hotza, A.P. Novaes de Oliveira, Ceram. Int. 37 (2011) 1865.

[28] O.R.K. Montedo, P.C. Milak, F.D. Minatto, R.B. Nuernberg, C.A. Faller, A.P.N. Oliveira, A. De Noni Jr., J. Therm. Anal. Calorim. 124 (2015) 241.
[29] R.G. Munro, J. Am. Ceram. Soc. 80 (1997) 1919.

[30] C.M. Gomes, N. Travitzky, P. Greil, W. Acchar, H. Birol, A.P. Novaes de Oliveira, D. Hotza, Rapid Protot. J. 17 (2011) 424.

[31] S. Arcaro, "Síntese, caracterização e processamento coloidal de compósitos nanoestruturados do sistema LZS $\left(\mathrm{Li}_{2} \mathrm{O}-\mathrm{ZrO}_{2}-\mathrm{SiO}_{2}\right)+\mathrm{Al}_{2} \mathrm{O}_{3}{ }^{\prime}, \mathrm{PhD}$ Thesis, Un. Fed. Santa Catarina, Brazil (2016).

[32] O. Dernovsek, A. Naeini, G. Preu, W. Wersing, M. Eberstein, W.A. Schiller, J. Eur. Ceram. Soc. 21 (2001) 1693. [33] C.J.D. Kumar, E.K. Sunny, N. Raghu, N. Venkataramani, A.R. Kulkarni, J. Am. Ceram. Soc. 91 (2008) 652.

(Rec. 25/06/2017, Rev.08/10/2017, 10/12/2017,03/02/2018, Ac. 06/02/2018) 